\title{
Campaign to shut plant
}

\section{Grelfswald, East Germany}

THE fate of East Germany's controversial Greifswald reactor complex is likely to be decided next month, when an investigatory commission reports to the East and West German governments. The commission was set up at the urging of the West German Environment Minister after the news magazine Der Spiegel revealed in January that one reactor had narrowly avoided a catastrophic accident in 1975.

Some experts at Greifswald believe the Soviet reactor design is fundamentally flawed. If they are judged correct, a shutdown could have dramatic repercussions in three other Eastern European countries where ten reactors of the same type are in operation. Four similar reactors are planned for Greifswald.

Two of the four operative 440-MW reactor blocks at Greifswald were temporarily shut down in February, on the advice of Western experts. The other two blocks continue to operate at lower power than normal, providing both power and heating for the nearby town of Greifswald (population 75,000) and environs.

Physicist Norbert Meyer, who heads a research group in materials science at the plant, says that the plant should be closed because of serious design flaws, many of which have already been identified in a preliminary report from the West German Society for Reactor Safety (GRS). Meyer says that he "cannot rule out that a serious accident might occur" at Block 1. Block 4 should be operated only as long as there is no other source of heat for the city of Greifswald, he says.

East German minister without portfolio Sebastian Pflugbeil of the New Forum says it is "irresponsible" to continue to operate the reactors. Pflugbeil is a member of the so-called 'round table' set up to oversee the transition government until this week's East German elections. As soon as the accident and continuing safety problems at the plant were revealed, he introduced a resolution at the round table to shut the plant. The government has not responded.

The most serious flaw is that the main and auxiliary control cables run in the same ducts and in some cases are not even redundant. In the 1975 accident, a fire destroyed the cables providing normal and emergency power. Only through a lucky accident - a single pump hooked up to an outside power supply - were plant operators able to avoid a meltdown and provide cooling water to the reactor for several hours until reserve power lines were installed.

The reactors are not protected against breaks in the pipes that deliver cooling water. A break in even one of the thin water lines, greater than $32 \mathrm{~mm}$ in dia- meter, could result in a meltdown. Western reactors are protected against breakage of cooling lines up to the largest pipes, which can reach $800 \mathrm{~mm}$ in diameter.

After 25 years of bombardment by neutrons, the steel walls of the reactor pressure vessels are dangerously brittle. This was the main reason that Blocks 2 and 3 were shut down last month. A break in the vessel, which contains water pressurized to 125 atmospheres, would lead to a meltdown.

Block 1, which went on line in 1973 , reached a level of brittleness far above the margin of safety by 1982 . But it took until 1988 before Block 1 was finally shut down for 'thermal annealing' - heating to $480^{\circ} \mathrm{C}$ for 120 hours to restore the tensile strength of the steel.

Block 2 passed the maximum safe level of brittleness in 1988, but was not shut down until earlier this year. Block 3, which went on line later - in 1977 - after modifications had been made in the design, was within a tiny fraction of the maximum when it was shut down in late February. Heinz-Peter Butz of GRS said it was "very hard to understand" why the plant operators did not shut down the blocks sooner.

The Soviets recognized the gravity of the problem in the mid-1980s and hurried to build a thermal annealing apparatus that could be used for all reactors of this type. But both Meyer and GRS say that it has not been proved that the annealing process restores the necessary tensile strength.

Many thousands of the tiny 'needle tubes' that are part of the steam generator have been severely corroded, according to Meyer, making the reactor vulnerable to a 'pressure wave' somewhere in the secondary cooling circuit. Such a wave, which could have many causes unconnected to the reactor itself, would again carry the risk of a possible meltdown.

Spokesman Peter Beier of the Greifswald plant says that "we don't claim that these reactors meet the safety standards of the $1990 \mathrm{~s}$ ", but all the nonsense about "time bombs" and "Chernobyls" that has appeared in the Western press is "horrendous nonsense". "We see no alternative" to rebuilding at least two of the four reactor blocks at Greifswald, said Beier. Despite the threat to the plant, the Greifswald management has not yet put forward an alternative plan for providing heating and electricity to the town.

Monika Litwin, spokeswoman for the Heavy Industry Ministry responsible for Greifswald, said that the plant "never caused any immediate danger to human lives", either in 1975 or at any other time.

After Meyer made public his charges, he had to face 800 of his co-workers at Greifswald, who demanded his immediate dismissal. Although he has been kept on, Meyer is no longer allowed into sensitive areas at the plant. "I am not considered reliable any more", he said. Steven Dickman

\section{Boston utility to foot bill}

\section{Boston}

IN a $\$ 215$-million plan that is the first of its kind, Boston Edison, one of New England's largest utility companies, will at least temporarily forestall the need for new power plants by paying instead for an array of energy conservation measures. The conservation programme, negotiated by representatives from the utility, state government and local environmental groups, is hailed by all three groups as a "revolutionary shift" and "a model of enormous importance for the rest of the nation".

The plan is expected to reduce the demand for electricity in the Boston area by a thousand million kilowatt hours over the next five years, roughly equivalent to the amount of power generated by a small $120-\mathrm{MW}$ power plant. It is particularly notable for its timing, announced shortly after the Seabrook nuclear power plant in neighbouring New Hampshire was cleared finally for its full-power licence after a gruelling and costly decade-long ordeal (see Nature 344, 96; 8 March 1990).

Boston Edison will invest immediately in measures such as making new buildings more energy-efficient than present standards require, retrofitting existing residential and commercial buildings and supplying energy-efficient light bulbs free or at low cost.

During the next five years, the utility expects to save two dollars' worth of electricity for every dollar invested. In an innovative economic incentive system, the utility will be allowed to retain a portion of this expected $\$ 400$ million in energy savings as profit in addition to recouping its costs. The rest of the savings will be passed on to customers. With such a market incentive, conservation becomes equally if not more profitable for the utility as the construction of new generating capacity.

Although conservation plans are not new, observers say that the Boston Edison announcement marks a trend towards a distinctly new movement on the part of electric utilities towards conservation. The intense opposition to the Seabrook nuclear power plant may be an extreme case, but is indicative of the difficulty of bringing any new power plants on line.

Seth Shulman 